and not as part of a public performance, was brought out by some of the Continental films, especially the instrumental films, shown at the International Folk. Dance Festival in London in 1935, which came as something of a revelation. It is satisfactory to note, therefore, that an attempt is to be made to remedy the deficiency in the equipment of folk-lore studies in Great Britain by an endeavour to secure a record of folk survivals, which will include not only folkdances and folk-customs, but also folk-crafts, which are in danger of extinction. The proposal, it is announced in a communication to The Times of March 7, is put forward on behalf of the Folklore Society, the English Folk-Dance and Song Society and the National Film Library. Sound films, it is also suggested, might be made of such activities as the almost extinct art of hand-bell ringing and of folk-dances in situ. The expense of carrying out such a scheme obviously will be considerable, and it is hoped that private benefaction will be forth. coming. In view, however, of the scientific and historical interest of local custom, whether ceremonial or industrial, the local museum, especially where an attempt is made to illustrate local antiquity and history at all adequately, might regard a subsidy in aid of a local film as a legitimate charge on its financial resources.

\section{The New Commonwealth}

THE eighth in the series of broadcast talks on "The Way of Peace" was given on March 3 by Lord Davies, who spoke on the New Commonwealth. This is, he said, a voluntary, international society, composed of members living in forty-six different countries, who have banded themselves together in order to enlist the support of public opinion for the establishment of two institutions-an equity tribunal or commission, and an international police force-as part of the permanent machinery of the League of Nations. No Government could carry on for a single week unless it possessed institutions capable of effecting changes in its laws, and the means of upholding them. How then can we expect the League to inaugurate the rule of law if its members refuse to give it those institutions essential for carrying out the responsibilities they have entrusted to it ? War can only be prevented by establishing intermational law and order on the same principles, and by the same methods, which have been successfully applied in the development of every civilized community. Lord Davies then dealt briefly with the two institutions in the New Commonwealth programme. The task of the equity tribunal would be to deal with any disputes which the League Council fail to settle by the existing procedure of negotiation and conciliation. The aim of the second point of the New Commonwealth programme, said Lord Davies, is the substitution of co-operative for competitive armaments. This can best be done by means of a police force under the control of the international authority. Only in this way, he considers, can the rule of law be established and the downfall of Western civilization averted.

\section{Gliding and Soaring Flight}

Ar the Friday evening discourse at the Royal Institution on March 4, Prof. D. Brunt discussed "Gliding and Soaring Flight". As the modern sailplane has a sinking speed in still air of 2-3 ft. per second, it will soar in an ascending current which rises faster than this modest limit. Three types of ascending currents occur in the atmosphere. Where the wind blows against the slope of a hill, it follows the contour of the ground, and if the air rises faster than the sinking speed of the sailplane, the latter can soar over the hill slope. Such a flight of 9 hours 48 minutes was carried out at the international competitions in Germany last summer, by Messrs. Fox and Murray in a Falcon III two-seater. When the air near the ground is heated until the rate of fall of temperature with height exceeds $5 \cdot 6^{\circ} \mathrm{F}$. per $1,000 \mathrm{ft}$., the air becomes unstable, and currents of warm air rise, and, if damp, give rise to clouds. Under the cumulus clouds then formed, the sailplane can mount in the rising air. When the wind increases with height the clouds are in long rolls, which have ascending air under their whole length, and in this air the sailplane can soar along the whole length of the cloud. In the rear of a depression, at the cold front, where the cold air pushes under warm air and forces it to rise, the rate of ascent of the warm air is often sufficient to enable a sailplane to soar. The British record for distance of soaring flight is 104 miles and was set up by Mr. Philip Wills. The world's record for distance, 405 miles, was set up by a Russian pilot in May, 1937.

\section{Asymmetric Sideband Broadcasting}

Mr. P. P. Eckersley in a paper read to the Institution of Electrical Engineers on March 2 said that the present methods of working permit few, except local radio broadcasting stations to be received without interference from other transmitters operating in contiguous frequency channels, unless the upper frequencies of modulation of the wanted station are severely attenuated. In this case the reproduction lacks intelligibility and naturalness. This can be mitigated without introducing audible harmonic distortion by utilizing the asymmetric sideband system of transmission to cut away with the aid of electrical filter circuits part of one sideband of the frequency spectrum radiated. In a previous paper, the author has shown how 'asymmetry', either of phase or of magnitude, between two sideband components is related to harmonic distortion. It is proportional to depth of modulation. He proved that as the sideband frequency becomes more and more removed from the carrier frequency, it may be more and more attenuated while the distortion can be made to remain constant and small. The author suggests that it is better to face the occasional minute deteriorations in quality given by the asymmetric system than to suffer from the continuous hissing and splitting sounds brought about by existing inter-station interference. The public insists that the radio-set exists to give pleasure. The attention that a user gives to a programme is de- 
termined partly by the quality of reproduction, but probably more by the freedom it enjoys from interference from extraneous sounds. It is primarily programme interest which pleases, but interference is very objectionable however good the programme. The author acknowledges his thanks to the B.B.C. for providing the funds for the construction of test apparatus. He also thanks the Countess von Zeppelin for her mathematical investigation, given in an appendix, resulting in a most useful expression for the distortion component.

\section{Reclamation of Tidal Lands}

Is a lecture delivered before the Royal Society of Arts on February 23, Mr. Oscar Borer described the process of land reclamation work as applied to the coastal frontages on both sides of the North Sea, tracing the origin of such operations to the time of the Romans under whose direction a bank was constructed across the Wash at some date prior to A.D. 359, and when other embankments were made between Lincoln and Norwich, aggregating not less than 50 miles in length and having a height of 10 feet. After the cessation of the Roman occupation, very little additional protection seems to have been undertaken along the British coastline until the seventeenth century, when during the reign of James I and afterwards, large tracts of marshlands, amounting to 35,000 acres, were excluded from tidal influence. During the eighteenth and nineteenth centuries, other areas approximating to 10,000 acres were reclaimed. Of the total quantity enclosed since Roman times, 8,000 acres was marshland in Norfolk along a frontage of ten miles, and 37,000 acres in the South Holland district of Lincolnshire with a frontage of nineteen miles, the remainder being in the North Holland district. In the Netherlands, from Roman times until the beginning of the fifteenth century, extensive areas were lost to cultivation through floods, the surface level of the land having sunk so that it was easily invaded. Early dikes made to offer defence against the sea broke down, and in this way the Dollart was formed in the twelfth or thirteenth century. The Zuider Zee, which had once been largely dry land, was inundated about the same time. The largest 'polder' recently reclaimed in this area is the Wieringermeer, in the north-west corner. It has an area of 48,000 acres and was dried in 1930. A second enclosure in the north-east corner was started in 1936, and it is expected that in due course another 110,000 acres will be available for agriculture. On the German North Sea coast, 8,000 acres has been embanked since 1900 in the province of Schleswig-Holstein.

\section{The Disappearing Fauna of Africa}

THE problem of the disappearing fauna of Africa formed the subject of a lecture before the University of London Animal Welfare Society on March 7. It has been common knowledge for years that the status of many of the big African animals was precarious. The last quagga died in 1882, and the three big pachyderms have been killed off at an alarming rate. Not only are the indigenous beasts being wiped out under the 'protecting' eye of a white civilization, but also the majority of many species are dying unnecessarily cruel deaths at the hands of the African native, working with old-fashioned guns and pitfalls and traps. Possibly only a few thousand gorillas remain alive to-day, in the Cameroons, where they are exploited by man, and in the Parc National Albert, where they are protected by the Belgian Government. The elephant has disappeared from most of its old haunts. In the three British dependencies a minimum of 6,000 a year are killed, chiefly in the 'control campaign'. Tanganyika and the lake swamps are the last haunts of the hippopotamus, and unless help is forthcoming this will eventually disappear. On November 8, 1933, the London Convention for the Protection of the African Fauna and Flora was signed. The first of a series of subsequent international conferences should have taken place before November 1937. No conference has been held, the reason given being that the British Government intends to summon a conference on tropical Asia and the western Pacific, certain of the experts interested in those regions being also interested in Africa. At the meeting, the Society passed a resolution calling upon the Government to take urgent steps for summoning the London Convention for the Protection of the African Fauna promised for November 1937.

\section{Locust Outbreaks in Africa and Western Asia}

THE recent report of the Committee on Locust Control is the sixth of its kind which deals with locust outbreaks in the regions mentioned. In the present instance it covers the year 1936 and the early part of 1937, and has been prepared by $\mathrm{Dr}$. B. P. Uvarov and Miss W. Milnthorpe. The report is a survey of the conditions in the territory named and is based upon the accumulated data which has come to hand as the result of international organization. It appears that the general situation, in so far as the African migratory locust and the red locust are concerned, is steadily improving. Particular stress, however, is laid on the beginning of a new outbreak of the desert locust which has been definitely proved to be forming in the Sudanese-Arabian area. It has been due to the regular system which is operating for the recording and collection of all data relating to locusts, and its centralization in a single institution (the Imperial Institute of Entomology), that the first signs of this outbreak have been recognized and warnings issued to all countries likely to be affected by the locust in question. The concerted measures which are being undertaken in order to endeavour to fathom the causes of locust outbreaks merit every support. The elaborate organization which has been built up and got into working order at the prime instigation of Dr. Uvarov provides the only sound method of attack-mere remedial measures are temporary palliatives and leave the locust menace unimpaired. At the present stage of the work, no effort should be relaxed, and it is up to the countries directly interested to see that the necessary funds are maintained. The report is available, price $3 s$. net, and is published by H.M. Stationery Office. 